\section{Epifluorescent microscopy to evaluate bacteriophage capsid integrity}

\author{
Kerusha Naicker and Steven I. Durbach \\ University of the Witwatersrand, Johannesburg, Gauteng, South Africa
}

BioTechniques 43:473-476 (October 2007)

doi: $10.2144 / 000112584$

The standard method to evaluate capsid integrity of DNA-based viruses, which depends on access to DNase I, relies on the removal of the capsid by solvent extraction and then the evaluation of the nucleic acid products by electrophoresis. Our method, which is based on the direct detection of capsid-borne DNA directly through the use of epifluorescent microscopy, negates the requirement of DNA extraction.

Virus capsid integrity can be measured indirectly by infectivity studies (1). A more informative method assesses capsid integrity by evaluating inaccessibility of DNase I to virus DNA. The efficacy of the DNase I treatment is evaluated by gel electrophoretic analysis of the extracted nucleic acid $(2,3)$.

In recent years, staining environmental samples with asymmetrical cyanine dyes (4), such as $\mathrm{SYBR}^{\circledR}$ Green I, and subsequent visualization with epifluorescent microscopy has become the standard approach for the detection of dsDNA bacteriophages and viruses $(5,6)$. The principle of this method is that the SYBR Green I dye is able to penetrate bacteriophage capsids and intercalate in the nucleic acid, displaying a significantly higher affinity for dsDNA than other nucleic acid types $(7,8)$. The dsDNA is concentrated within the capsid and accordingly is detectable as dots under $1000 \times$ magnification using epifluorescent microscopy (5).

Given the robustness of this method, we reasoned that it could be adapted to a simple assay for capsid integrity with the advantage of circumventing solventmediated disruption of the capsids following destabilizing treatments, which does not depend on solvent sensitivity of capsid proteins. This will allow an in situ confirmation of DNase I sensitivity. We used epifluorescent microscopy to analyze destabilized T4 virions for DNase I accessibility by their ability to be stained by SYBR I Green dye.
Capsids were destabilized by heat treatment of CsCl-purified $\mathrm{T} 4$ phage (9). This was done by dispensing $1 \mathrm{~mL}$ T4 [109 plaque forming units (pfu)] contained in phage buffer $(10 \mathrm{mM}$ Tris, $\mathrm{pH} 8.0,10 \mathrm{mM} \mathrm{MgSO}_{4}, 68 \mathrm{mM} \mathrm{NaCl}$, $10 \mathrm{mM} \mathrm{CaCl} 2$ ) into glass McCartney bottles and boiling $\left(98^{\circ} \mathrm{C}\right)$ for $20 \mathrm{~min}$. Plaque overlays showed undetectable viability following this treatment (data not shown). Transmission electron microscopy (TEM) was done to assess the impact of the heat treatment on capsid structure. Approximately $5 \mu \mathrm{L}$ sample (titer $=1 \times 10^{6} \mathrm{pfu} / \mathrm{mL}$ ) were placed on carbon-coated Formvar grids for $20 \mathrm{~min}$. The excess fluid was gently drawn off with filter paper. Five microliters of stain (1\% uranyl acetate in $45 \%$ ethanol) were then placed on the grid for $3 \mathrm{~min}$, and excess fluid was drawn off with filter paper. The grids were washed with double deionized water, and the excess fluid drawn off. The grids were then dried for $48 \mathrm{~h}$ at room temperature before being viewed under the transmission electron microscope (JEOL-JEM100S, Japan). TEM confirmed capsid destabilization (Figure 1B) compared with the untreated $\mathrm{T} 4$ phage control (Figure 1A) in that the heat-treated capsids appeared deformed yet intact. We then investigated whether the heattreated capsids were detectable by epifluorescent microscopy essentially as described by Noble and Fuhrman (5); although rather than environmental material, 1-5 mL CsCl-purified T4 (titer: $1 \times 10^{6} \mathrm{pfu} / \mathrm{mL}$ ) were filtered through a $0.02-\mu \mathrm{M}$ Anodisc ${ }^{\circledR} 25$ filter
(Whatman, Kent, UK). The staining method followed was also as described by Noble and Fuhrman (5), in which the Anodisc containing filtered material was submerged in $0.25 \%$ SYBR Green I working solution (an optical density of 0.42 at $494 \mathrm{~nm}$ when the stock is diluted 1000 -fold in sterile deionized water) for $15 \mathrm{~min}$ in the dark. Following staining, the filter was removed from the stain, and additional moisture was carefully removed using KimWipes ${ }^{\circledR}$ (Kimberly-Clark, Bedfordview, Gauteng, South Africa). The Anodisc filter was then mounted on a glass slide containing a drop of $50 \%$ glycerol, $50 \%$ phosphate-buffered saline (PBS; $0.05 \mathrm{M} \mathrm{Na}_{2} \mathrm{HPO}_{4}, 0.85 \%$ $\mathrm{NaCl}, \mathrm{pH} 7.5)$ with $0.1 \%$ phenylenediamine, and covered with a $25-\mathrm{mm}$ square coverslip prior to viewing under oil immersion $(1000 \times$ magnification) under (UV) blue excitation using a Zeiss Axioskop ${ }^{\circledR} 2$ plus microscope (Carl Zeiss, Poughkeepsie, NY, USA) as described (5). The heat-treated T4 samples were still detectable by epifluorescent microscopy (Figure 2C) similar to the untreated control (Figure 2A).

We then investigated whether the destabilized capsids were DNase I

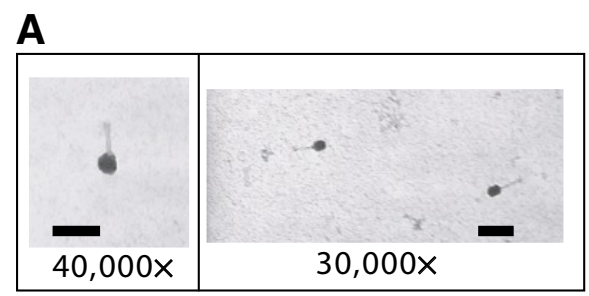

B

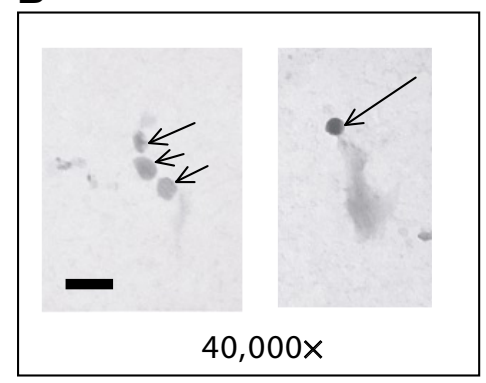

Figure 1. Transmission electron microscopy (TEM) of heat-treated T4 phage. (A) Untreated phage. (B) Heat-treated T4 phage. Magnification is indicated in the figure. Arrows indicate heat-treated capsid. Scale bar, $0.2 \mu \mathrm{M}$. Representative images of the entire preparation were captured by standard photography, and negatives were scanned with an Epson ${ }^{\circledR}$ Perfection ${ }^{\circledR} 4870$ scanner. 


\section{Benchmarks}
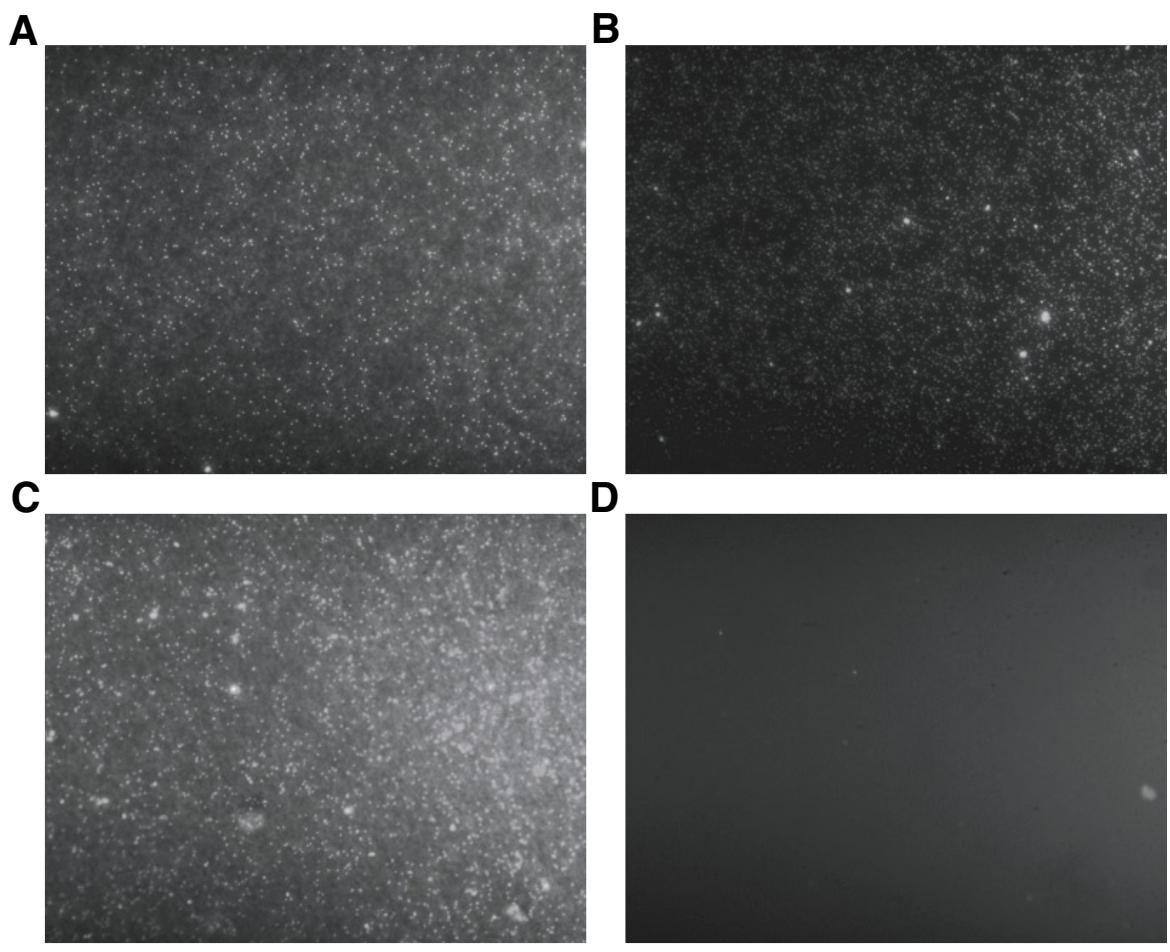

Figure 2. Epifluorescent microscopy of DNase I heat-treated T4 phage virions. (A and B) CsCl-purified T4 not subjected to heat treatment. (C and D) Heattreated CsCl-purified T4 virions. Panels A and C show DNase I-negative virions; whereas panels B and D show DNase I-treated virions.

sensitive. Both the heat-treated and untreated capsids were administered with DNase I as follows: CsCl-purified T4 stock $\left(1 \times 10^{6} \mathrm{pfu} / \mathrm{mL}\right)$ in buffer [1 $\mathrm{mM}$ Tris- $\mathrm{HCl}, \mathrm{pH} 7.5,1 \mathrm{mM} \mathrm{MgCl}{ }_{2}, 5$ $\mathrm{mM} \mathrm{NaCl}, 0.01 \mathrm{mg} / \mathrm{mL}$ bovine serum albumin (BSA)] was combined with 3 U DNase I (Fermentas, Hanover, MD, USA), incubated for $60 \mathrm{~min}$ at $37^{\circ} \mathrm{C}$ and visualized by epifluorescent microscopy as described. Untreated capsids continued to fluoresce following DNase I treatment (Figure 2B), similar to previous observations with environmental phage samples (10), while heat-treated capsids lost the fluorescent signal following DNase I treatment (Figure 2D), confirming that the heat-treated capsids were DNase I accessible.

In conclusion, we showed that heat-treated $\mathrm{T} 4$ capsids retained the gross structural features of the virion but appeared deformed. Furthermore, epifluorescent microscopy revealed that exposure of heat-treated T4 capsids to DNase I abrogates the fluorescent signal that can then be detected in situ without the requirement for extracting DNA from the capsid. Together, these observations suggest a simple method for evaluating capsid structural deformation using epifluorescent microscopy in conjunction with DNase I. The assay should be applicable to any treatment or condition that might alter the capsid's accessibility to DNase I - the hallmark of destabilized capsids. Most dsDNA viruses and phages are DNase I resistant in their native form $(11,12,13)$, and therefore the method should be generally applicable to these DNA-based viruses.

\section{ACKNOWLEDGMENTS}

The authors are indebted to Rodney Hull for his excellent technical support with the epifluorescent microscope; Carolyn Lalkin for technical support with the electron microscope; Dr. Monde Ntwasa for advice; the National Research Foundation (NRF) for financial assistance; and Tracy McLellan, Denise Lindsay, Digby
Warner, and Nathalie Fernandes for critically reviewing the manuscript.

\section{COMPETING INTERESTS STATEMENT}

The authors declare no competing interests.

\section{REFERENCES}

1. Colby, W.W. and T. Shenk. 1981. Adenovirus Type $\mathrm{V}$ virions can be assembled in vivo in the absence of detectable polypeptide IX. J. Virol. 39:977-980.

2. Li, M., P. Beard, P.A. Estes, M.K. Lyon, and R.L. Garcea. 1998. Intercapsomeric disulfide bonds in papillomavirus assembly and disassembly. J. Virol. 72:2160-2167.

3. Stow, N.D. 2001. Packaging of genomic and amplicon DNA by the Herpes Simplex Virus type I UL25-null mutant KUL25NS. J. Virol. 75:10755-10765.

4. Hennes, K.P. and C.A. Suttle. 1995. Direct counts of viruses in natural waters and laboratory cultures by epifluorescence microscopy. Limnol. Oceanogr. 40:1054-1059.

5. Noble, R.T. and J.A. Fuhrman. 1998. Use of SYBR I Green for rapid epifluorescence 


\section{Benchmarks}

counts of marine viruses and bacteria. Aquat. Microb. Ecol. 14:113-118.

6. Williamson, S.J., L.A. Houchin, L. McDaniel, and J.H. Paul. 2002. Seasonal variation in lysogeny as depicted by prophage induction in Tampa Bay, Florida. Appl. Environ. Microbiol. 68:4307-4314.

7. Vitzthum, F., G. Geiger, H. Bisswanger, $\mathbf{H}$. Brunner, and J. Bernhagen. 1999. A quantitative fluorescence-based microplate assay for the determination of double-stranded DNA using SYBR Green I and a standard ultraviolet transilluminator gel imaging system. Anal. Biochem. 276:59-64.

8. Zipper, H., H. Brunner, J. Bernhagen, and F. Vitzthum. 2004. Investigation on DNA intercalation and surface binding by SYBR Green I, its structure determination and methodological implications. Nucleic Acids Res. 32:e103.

9. Sambrook, J., E.F. Fritsch, and T. Maniatis. 1989. Molecular Cloning: A Laboratory Manual, 2nd ed. Cold Springs Harbor Laboratory Press, New York.

10. Fischer, U.R., W. Weisz, C. Wieltschnig, A.K.T. Kirschner, and B. Velimirov. 2004. Benthic and pelagic viral decay experiments: a model-based analysis and its applicability. Appl. Environ. Microbiol. 70:6706-6713.

11. Allander, T., S.U. Emerson, R.E. Engle, R.H. Purcell, and J. Bukh. 2001. A virus discovery method incorporating DNase treatment and its application to the identification of two bovine parvovirus species. Proc. Natl. Acad. Sci. USA 98:11609-11614.

12. Barbian, K.D. and M.F. Minnick. 2000. A bacteriophage-like particle from Bartonella bacilliformis. Microbiology 146:599-609.

13. Maruyama, A., M. Oda, and T. Higashihara. 1993. Abundance of virus-sized non-DNAse-digestible DNA (coated DNA) in eutrophic seawater. Appl. Environ. Microbiol. 59:712-717.

Received 16 April 2007; accepted 24 August 2007.

Address correspondence to Steven I. Durbach, School of Molecular and Cell Biology, Private Bag 3, University of the Witwatersrand, Johannesburg, South Africa 2050.e-mail:durbach@biology.biol.wits. ac.za

To purchase reprints of this article, contact: Reprints@BioTechniques.com 